\title{
Quantitative analysis of bone marrow in pancytopenic dogs
}

\section{Análise quantitativa de medula óssea em cães pancitopênicos}

\author{
Angela Ferronato Girardi1; Amanda Noeli Campos²; Caroline Argenta Pescador ${ }^{3}$; \\ Arleana do Bom Parto Ferreira de Almeida ${ }^{3}$; Adriane Jorge Mendonça ${ }^{3}$; Luciano \\ Nakazato $^{3}$; Anderson Castro Soares de Oliveira ${ }^{4}$; Valeria Régia Franco Sousa ${ }^{3}$
}

\begin{abstract}
The pancytopenia can be associated with intra and extra medullary disorders. When the etiology is not obvious, the examination of bone marrow is necessary. The study aims to report and discuss quantitative amendments in bone marrow and their causes in dogs with pancytopenia. Bone marrow aspirate was obtained from 65 dogs with pancytopenia over a period of 13 consecutive months for preparation of smears stained by Giemsa and observed in light microscopy. Five hundred cells differential count was held; and assessed myeloid:erythroid ratio, cellularity, megakaryocytes and direct parasitological examination. The data were evaluated by the Chi-square statistical test. Blood tests of 3120 canines with several clinical changes were analyzed to identify pancytopenia, which accounted for 167 (5.4\%) dogs. Interpretation of quantitative characteristics was carried out from the bone marrow smear in 65 pancytopenic dogs and the etiology was established in 40 (61.5\%) of these, which included infection by $E$. canis and L. chagasi, idiopathic aplastic anemia, chronic renal failure and co-infections. In 17 $(26.2 \%)$ animals were not observed medullary changes. The most bone marrow change was observed myeloid and erythroid hypoplasia in $17(26.2 \%)$ dogs, followed by myeloid and erythroid hyperplasia (24.6\%). The myelogram association to the blood cell count allowed the identification of medullary findings and its participation on the occurrence of pancytopenia cases. The number of cases resulting from infectious diseases was $38(58.5 \%)$ in canine assessed: significant number due to its endemic characteristic of the study region.
\end{abstract}

Key words: Cytology. Canine. Cytopenia. Hemoparasites. Myelogram.

\section{Resumo}

A pancitopenia pode estar associada a distúrbios intra e extra medulares. Quando a etiologia não é óbvia, o exame da medula óssea é necessário. Este estudo tem como objetivo relatar e discutir alterações quantitativas na medula óssea e suas causas em cães com pancitopenia. De 65 cães pancitopêncicos atendidos durante um período de 13 meses consecutivos, foram realizados aspirados de medula óssea, corados com Giemsa, e observados em microscopia de luz. Quinhentas células foram observadas para contagem diferencial, razão mieloide: eritróide, celularidade, megacariócitos e exame parasitológico direto. Os dados foram avaliados pelo teste estatístico Qui-quadrado. Hemograma de 3120 caninos com diversas alterações clínicas foram analisadas para identificar a pancitopenia, encontrada em 167 (5,4\%) cães. A interpretação das características quantitativas foi realizada a partir do esfregaço de medula óssea em 65 cães pancitotopênicos e a etiologia foi estabelecida em 40 (61,5\%), incluindo infecção por

\footnotetext{
${ }^{1}$ Discente, Programa de Pós-graduação em Ciências Veterinárias, Universidade Federal de Mato Grosso, UFMT, Cuiabá, MT, Brasil. E-mail: angel_agir@hotmail.com

2 Discente de Graduação em Medicina Veterinária, UFMT, Cuiabá, MT, Brasil. Voluntária de Iniciação Científica. E-mail: amanda. noeli@hotmail.com

${ }^{3}$ Profs., Faculdade de Medicina Veterinária, UFMT, Cuiabá, MT, Brasil. E-mail: carolpescador@yahoo.com.br; arleferreira@ gmail.com; adrianejorge.m@gmail.com; lucnak@ufmt.br; valeriaregia27@gmail.com

* Author for correspondence
} 
E. canis e L. chagasi, anemia aplástica idiopática, insuficiência renal crônica e co-infecções. Em 17 $(26,2 \%)$ cães não foram observadas alterações medulares. A alteração de medula óssea mais observada foi a hipoplasia mielóide e eritróide em 17 (26.2\%) cães, seguido pela hiperplasia mielóide e eritróide (24.6\%). A associação do mielograma ao hemograma permitiu a identificação de achados medulares e sua participação na ocorrência de casos de pancitopenia. O número de casos resultantes de doenças infecciosas foi de $38(58,5 \%)$ em caninos avaliados: número significativo devido à característica endêmica da região do estudo.

Palavras-chave: Citologia. Canino. Citopenia. Hemoparasitas. Mielograma.

\section{Introduction}

The bone marrow hematopoietic tissue is the main responsible for storing the myeloid, erythroid and megakaryocytic precursors (STOKOL, 2010). Up to recently, bone marrow disorders in animals were rarely evaluated (WEISS, 2003). Currently, the bone marrow examination is a valuable diagnostic tool for the veterinarian; and the sample can be easily obtained (STACY; HARVEY, 2017).

Medullary disorders that include decreased hematopoiesis or its ineffectiveness can lead to pancytopenia, consisting of the decrease in cell number of the three lineages presents in the peripheral blood. This hematologic condition may be related to peripheral destruction of the blood cells (WEISS et al., 1999).

The occurrence of the hematological condition is described by some authors and varies according to the geographic studied area, whose variation can occur according to the endemic character of infectious diseases that cause it (WEISS, 2006). Prevalence of $1.85 \%$ to $2.4 \%$ are reported in studies conducted in the United States (WEISS et al., 1999; BRAZZELL; WEISS, 2006). In Brazil there is no recorded data in the occurrence of pancytopenia in dogs.

Pancytopenia usually represents a diagnostic challenge for presenting a high variability of etiologies. For this reason, when the etiology is not obvious, the biopsy or bone marrow aspiration cytology is necessary (WEINZIERL; ARBER, 2013). The cytological examination allows to demonstrate a more detailed cellular morphology and is indicated for neoplasia staging and diagnosis, iron store estimate and unkown fever origin evaluation (STOKOL, 2010). Quantitative abnormalities also should be evaluated to the myelogram and require simultaneous evaluation of peripheral blood for proper interpretation (REBAR, 1993).

The myelogram still allows the detection of hemoparasites, including protozoan, fungal, and bacterial infections (STOKOL, 2010) that can be associated with pancytopenia. Its importance increases as regards the diagnosis of endemic infectious diseases, as in the present study location: canine monocytic ehrlichiosis (CME) and canine visceral leishmaniasis (CVL) (SILVA et al., 2010; ALMEIDA et al., 2012). A variety of medullary responses to caused stress by various infections and parasitism have been related (DE TOMMASI et al., 2014).

With the intention of clarifying the causes of pancytopenia in dogs, little discussed in Brazil, the study aims to report and discuss quantitative changes in bone marrow and its causes in pancytopenic dogs.

\section{Materials and Methods}

This study was approved by the Animal Ethics Committee of the Federal University of Mato Grosso protocol 23108.017857 / 12-2.

Sixty five dogs with pancytopenia were assisted in Veterinary Teaching Hospital and collected bone marrow aspirate samples(in which there was authorization from the owners), located in the midwest of Brazil. Data as age, sex, breed, clinical signs, history of exposure to myelo-suppressor drugs were collected. 
Pancytopenic dogs without authorization for anesthesia for sample collection or with insufficient samples were excluded from the study.

Pancytopenia was defined according to the following values of reference $(\mathrm{HCT}<37 \%$; WBC $<$ $6 \times 10^{3} / \mu \mathrm{L}$ and platelets $\left.<200 \times 10^{3} / \mu \mathrm{l}\right)(\mathrm{JAIN}, 1993)$ from automated CBC (Sysmex PocH -Diff 100iV (®) Veterinary Hematology Analyzer, Sysmex, Latin America 1659) and cytopenias have been classified according to severity (WEISS et al., 1999).

Collection procedures were carried out after anesthesia [ketamine (Cetamin, Rhobifarma, Brazil) and midazolam (Midazolam, Hipolabor, Brazil) at a dose of $10 \mathrm{mg} / \mathrm{kg}$ and $0.5 \mathrm{mg} / \mathrm{kg}$, respectively, and local anesthetic button with lidocaine $2 \%$ without vasoconstrictor (2 to $5 \mathrm{mg} / \mathrm{kg}, \mathrm{L}$ Anesthetic, Eurofarma, Brazil)], trichotomy and antisepsis of the region of the iliac crest or sternum. Bone marrow samples were collected up to $24 \mathrm{~h}$ after the CBC.

The technique consisted of the aspiration of $1 \mathrm{~mL}$ fraction of bone marrow, via transiliac or sternal, 40x12mm needle and $20 \mathrm{ml}$ syringe, adding $3 \%$ EDTA for performing smear. The smears were submitted from Giemsa staining (Azur-eosinmethylene blue solution, Merck ${ }^{\circledR}$, Germany), while another sample aliquot was wrapped on microtube and stored at $-20^{\circ} \mathrm{C}$. After DNA extraction from the bone marrow samples by the chloroform phenol method (SAMBROOK et al., 1989), PCR was performed for Ehrlichia canis (MURPHY et al., 1998) and Leishmania chagasi (LACHAUD et al., 2002).

The differential count was conducted from 500 cells in each smear, in an optical 40x microscope, counting only arranged cells without overlap, discriminating cellular types (JAIN, 1993; STACY; HARVEY, 2017), as well as megakaryocytes. The myeloid: erythroid ratio (MER) and cellularity were joint assessed and interpreted (STACY; HARVEY, 2017) and grouped according to the quantitative changes and severity of cytopenias.

The dogs were followed regarding the clinical evolution, while pancytopenia therapeutic approach, and this was confronted with the cytopenia severity.

The association between the obtained results in this study were evaluated through R software (www. cran.r-project.org), by Chi-square test or Fischer's exact. The differences were considered significant when the p-value was $<0.05$.

\section{Results}

In the study period, 3840 blood counts of 3120 canines with several clinical changes were performed; among which 167 (5.4\%) presented pancytopenia. From these, 65 (2.1\%) dogs comprised the canine group, whom bone marrow was examined.

The average age of evaluated dogs was 3.5 years, ranging from two months to 13 years. Females were represented by $38(58.5 \%)$ and males $27(41.5 \%)$ animals. Animals with defined breed included 37 (56.9\%) animals, while $28(43.1 \%)$ had no breed definition.

The most frequent clinical signs were anorexia $(56=86.2 \%)$, lymphadenomegaly $(47=72.3 \%)$, pallor of mucous membranes $(45=69.2 \%)$, weight loss $(38=58.5 \%)$ and digestive signs $(33=50.8 \%)$. The owners have not reported the use of myelosupressor drugs.

According to the findings in hematology, the most common anaemia form was severe, in $29(44.6 \%)$ dogs, followed by mild anaemia in $22(33.8 \%)$ and moderate in $14(21.6 \%)$. About neutropenia, $23(35.4 \%)$ dogs presented mild, 19 (29.2\%) the severe form, 15 (23.1\%) presented leukopenia with no neutropenia and eight (12.3\%) moderate. Severe thrombocytopenia was the most often, in $33(50.8 \%)$ dogs, followed by moderate thrombocytopenia in $28(43.1 \%)$ and mild in four (6.1\%) dogs.

In relation to the count of megakaryocytes, $40(61.5 \%)$ animals presented low estimate of 
megakaryocytes (zero megakaryocytes/field), megakaryocytes/field, being 15 (23.1\%) of these whereas $24(36.9 \%)$ had severe thrombocytopenia, presenting moderate thrombocytopenia, followed $13(20 \%)$ moderate and $3(4.6 \%)$ mild. Normal by nine (13.8\%) with severe and one with mild.

megakaryocytes estimate was displayed in $25(38.5 \%)$ dogs, that presented one to six

Quantitative changes were investigated in all animals and they are associated with severity of cytopenias (Tables 1 and 2).

Table 1. Interpretation of the myeloid: erythroid ratio and cellularity in pancytopenic canines.

\begin{tabular}{cccc}
\hline Myeloid:Erythroid Ratio & Cellularity & Interpretation & Canines \\
\hline \multirow{3}{*}{ Normal } & Normal & Normal & $17(26.2 \%)$ \\
& Increased & Erythroid and myeloid hyperplasia & $16(24.6 \%)$ \\
& Decreased & Erythroid and myeloid hypoplasia & $17(26.2 \%)$ \\
& Normal & Myeloid hyperplasia and erythroid hypoplasia & $1(1.5 \%)$ \\
Increased & Increased & Myeloid hyperplasia & $3(4.6 \%)$ \\
& Decreased & Erythroid hypoplasia & $2(3.1 \%)$ \\
& Normal & Erythroid hyperplasia and myeloid hypoplasia & $3(4.6 \%)$ \\
Decreased & Increased & Erythroid hyperplasia & $1(1.5 \%)$ \\
& Decreased & Myeloid hypoplasia & $5(7.7 \%)$ \\
\hline
\end{tabular}

Table 2. Severity of hematologic data and the quantitative characteristics of bone marrow cytology in pancytopenic canines.

\begin{tabular}{cccccl}
\hline \multirow{2}{*}{ Quantitative bone marrow alteration } & Severity & \multirow{2}{*}{ Mild } & Moderate & Severe & \multicolumn{2}{c}{ P-value } \\
\cline { 2 - 4 } Normal & Cytopenias & & & & \\
& Anemia & 7 & 5 & 5 & 0.2525 \\
& Neutropenia & 8 & 3 & 1 & 0.07503 \\
Myeloid and erythroid hyperplasia & Anemia & 8 & 6 & 2 & $0.004846^{*}$ \\
& Neutropenia & 8 & 2 & 1 & 0.08754 \\
Myeloid hypoplasia & Anemia & 1 & 0 & 4 & 0.2509 \\
& Neutropenia & 0 & 0 & 4 & $0.009379^{*}$ \\
Myeloid and erythroid hypoplasia & Anemia & 4 & 1 & 12 & $0.04547^{*}$ \\
& Neutropenia & 1 & 3 & 10 & $0.00196^{*}$ \\
Erythroid hyperplasia /myeloid hypoplasia & Anemia & 0 & 1 & 2 & 0.4447 \\
& Neutropenia & 2 & 0 & 1 & 0.5035 \\
Myeloid hyperplasia & Anemia & 0 & 0 & 3 & 0.09295 \\
& Neutropenia & 2 & 0 & 1 & 0.5035 \\
Erythroid hypoplasia & Anemia & 0 & 1 & 1 & 0.488 \\
& Neutropenia & 1 & 0 & 1 & 0.5601 \\
Erythroid hyperplasia & Anemia & 0 & 0 & 1 & 0.4615 \\
& Neutropenia & 1 & 0 & 0 & 0.3538 \\
Erythroid hypoplasia/myeloid hyperplasia & Anemia & 1 & 0 & 0 & 0.3231 \\
& Neutropenia & 0 & 0 & 0 & 0.2308 \\
\hline
\end{tabular}

* the significance level is $5 \%$ for Chi-square test or Fischer's exact. 
The etiology was established in $40(61.5 \%)$ pancytopenics canine, $11(27.5 \%)$ without medullary changes and $29(72.5 \%)$ with medullary changes. From $11(27.5 \%)$ dogs without medullary changes, five (45.5\%) were positive for E. canis, four (36.3\%) for L. chagasi, one (9.1\%) for Babesia sp. and one (9.1\%) for Babesia sp and E. canis co-infection. From 29 (72.5\%) dogs with medullary disorders, 16 (55.2\%) were positive for E. canis, seven (24.1\%) for L. chagasi, two (6.9\%) for L. chagasi and E. canis co-infection, one (3.4\%) for each: Hepatozoon sp., distemper virus, sepsis and chronic renal disease. In $25(38.5 \%)$ dogs it was not possible to conclude the diagnosis, six (24\%) had no bone marrow changes, five $(20 \%)$ presented aplasia while $14(56 \%)$ had other marrow changes. In these 14 dogs without etiological diagnosis, bone marrow findings were myeloid and erythroid hypoplasia (5/35.7\%), followed by myeloid and erythroid hyperplasia (3/21.4\%), myeloid hypoplasia (3/21.4\%), myeloid hyperplasia, erythroid hypoplasia, and erythroid hyperplasia associated with Myeloid hypoplasia with one $(7.1 \%)$ dog each.

Myeloid and erythroid hyperplasia was observed in seven (10.8\%) positive dogs for E. canis, three (4.6\%) for L. chagasi, three $(4.6 \%)$ dogs were inconclusive, two $(3.1 \%)$ presented co-infection by L. chagasi and E. canis and one reported gamonts of Hepatozoon sp.

Two cases of infection by E. canis and three inconclusive showed myeloid hypoplasia, while myeloid and erythroid hypoplasia occurred in six dogs with aplastic anaemia probably of idiopathic origin, five (7.7\%) dogs diagnosed as inconclusive, followed by infection by $E$. canis in three (4.6\%), by L. chagasi in one, aplastic anemia associated with sepsis for Staphylococcus sp in one and in another with aplasia associated with L. chagasi positivity.

Erythroid hyperplasia concomitant with myeloid hypoplasia occurred in two dogs infected by $E$. canis; one with Lentz corpuscle; and in another was not signed etiological diagnosis.
Myeloid hyperplasia occurred in two dogs infected by $L$. chagasi and in one does not obtained diagnosis. Erythroid hypoplasia occurred in one dog infected by E. canis and other with chronic renal failure. Erythroid hyperplasia occurred in one dog with hemolysis signs and infection by $E$. canis. Erythroid hypoplasia concomitant to myeloid hyperplasia was observed in one dog infected with E. canis.

From 65 dogs, 17 (26.2\%) came to death during therapeutic approach of primary disease. Nine (13.8\%) were submitted to euthanasia. Among the $19(29.2 \%)$ dogs that showed severe neutropenia, 12 (18.5\%) came to death. About the clinical outcome, all dogs with probably idiopathic aplastic anaemia came to death.

There were statistically significant associations between severity of cytopenias and some quantitative changes, regardless of etiology. The significant statistical associations can be found in Table 2.

\section{Discussion}

The prevalence of pancytopenia found (5.4\%) is higher than the reported elsewhere, a fact that is due to some infectious disease endemicity that cause it, as the CME (SILVA et al., 2010) and the CVL (ALMEIDA et al., 2012) that represented 35 (53.8\%) cases. A study in the United States evaluated 4560 animals where $2.4 \%$ were pancyitopenics (WEISS et al., 1999). Another study in the same teaching hospital identified the non-endemic character for some diseases in the region, scoring as a possible factor that could explain their smaller found prevalence (WEISS, 2006).

Authors report no sexual predisposition to pancytopenia. Breed predisposition was also not associated with (BRAZZELL; WEISS, 2006). The reported clinical signs, in majority, were unspecific. Clinical signs deriving from pancytopenia are related to the lower rate of cells (anaemia, 
leukopenia and thrombocytopenia) and underlying diseases (KEARNS; EWINGS, 2006).

There was no report on myelo-supressor drug use, which was representative in another study due to the broad oncology service developed in that locality, which does not apply to this study location (WEISS, 2006).

Most part of animals presented severe anaemia and thrombocytopenia. In cases involving precursor or progenitor cells in the bone marrow, cytopenias present as moderate to severe for chronic progress injuries, which may have occurred in these cases. Thus, in acute disease development, leukopenia and thrombocytopenia may slightly occur before anaemia, generally, due to the increased half-life period of erythrocytes (KEARNS; EWINGS, 2006).

Animals with normal megakaryocytes estimate mostly had moderate to severe thrombocytopenia, which can be attributed to stimulation of megakaryocytes to synthesize platelet in greater quantity due to an immune-mediated destruction (MUHURY et al., 2009).

The absence of medullary changes was observed in $26.2 \%$ dogs, and myeloid and erythroid hypoplasia was observed in the same percentual, followed by hyperplasia of the myeloid and erythroid series with $24.6 \%$. This fact coupled with pancytopenia infers that the citopenia origin is due to peripheral destruction, sequestration or ineffective hematopoiesis where cell death can occur in the intramedullary compartment (STOKOL, 2010; KEARNS; EWINGS, 2006).

Viral infections can attack stem cells, causing transient hypoplasia, which may have occurred to the animal with evidence of canine distemper virus infection. The neutrophil short half-life enhances the effect of a transient reduction in their production and may result in leukopenia (REBAR, 1993). Although there is hyperplasia, it is known that the canine distemper virus may lead to a high apoptotic index, culminating to peripheral blood cytopenias (ALMEIDA et al., 2009).
The myeloid hyperplasia cases here in described may have occurred due to L. chagasi infection, which is considered a chronic disease. In cases of chronic inflammation, all medullary granulocyte compartments are increased, as well as bone marrow cellularity (REBAR, 1993; IKEDA-GARCIA et al., 2008).

Erythroid hyperplasia, which was due to ehrlichiosis in this study, occurs when there is an increase in demand for peripheral erythrocytes, as in cases of hemolysis. Dogs with babesiosis, although showing normal values of MER, they were near the lower limit, suggesting that they might be evolving into an erythroid hyperplasia. In most cases, bone marrow is collected after a significant anaemia level with considerable severity, as in dogs with this medullary finding, due to prolonged hemolysis duration (REBAR, 1993).

Pancytopenic dogs should be evaluated for developing sepsis or this being the pancytopenia cause. The neutrophil left shift in CBC might be the point in predicting whether sepsis is the cause or a consequence of hematologic condition. Its absence, as in the animal mentioned earlier, suggests that bone marrow suppression is linked to another cause and sepsis condition is secondary. Once when sepsis is the primary pancytopenia cause, there is an increase in leucopoiesis and mature cell mobilization, resulting in a left shift (WEISS, 2005).

In addition to the discussed cases, pancytopenia may also occur in cases where there is only one change in medullary lineage, which can be explained by the fact that a cytopenia can lead to others by immune-mediated mechanisms (JAIN, 1993).

The frequency of possible idiopathic aplastic anaemia cases was relatively high. The pathogenesis is unclear, but by the response to immunosuppressive therapy presented, there is an evidence of immunemediated mechanism (WEISS, 2003; WEISS et al., 1999; BRAZZELL; WEISS, 2006). In the event of pancytopenia, it can be deduced a chronic aplasia, since the half-life of erythrocytes is long, 
the last citopenia to occur. Many cases of aplastic pancytopenia are often not diagnosed. In a teaching hospital, $77.8 \%$ of dogs with pancytopenia and medullar hypocellularity did not receive etiological diagnosis from their bone marrow smear analysis or exposure history to myelosuppression causative agents. Then, the authors reported a idiopathic aplastic pancytopenia diagnosis (BRAZZELL; WEISS, 2006).

More than half of the animals with severe neutropenia came to death during therapy approach. The clinical outcome depends on the pancytopenia associated cause. Therefore, it is needed a conclusive diagnosis to outline a prognosis (WEISS et al., 1999).

\section{Conclusion}

Through myelogram and $\mathrm{CBC}$ was possible to identify the medullary quantitative changes and their influence on pancytopenia. In 40 (61.5\%) of the evaluated animals, the etiologic agents were identified. Infectious diseases reported here as causes of pancytopenia are often more expressive before its endemic feature. The severity of cytopenias can aid in prognosis, since it can reflect the medullary signs during the myelogram.

\section{Acknowledgements}

The CAPES (Coordination of Improvement of Higher Education Personnel) by promotion through granted scholarship.

\section{References}

ALMEIDA, A. B. P. F.; SOUSA, V. R. F.; CRUZ, F. A. C. S.; DAHROUG, M. A. A.; FIGUEIREDO, F. B.; MADEIRA, M. F. Canine visceral leishmaniasis: seroprevalence and risk factors in Cuiabá, Mato Grosso, Brazil. Revista Brasileira de Parasitologia Veterinária, Jaboticabal, v. 21, n. 4, p. 359-365, 2012.
ALMEIDA, R. K.; VASCONCELOS,A. C.; CARNEIRO, R. A.; PAES, P. R. O.; MORO, L. Alterações citológicas do sangue periférico e da medula óssea de cães com cinomose. Arquivo Brasileiro de Medicina Veterinária e Zootecnia, Belo Horizonte, v. 61, n. 6, p. 1255-1260, 2009.

BRAZZELL, J. L.; WEISS, D. J. A retrospective study of aplastic pancitopenia in the dog: 9 cases (1996-2003). Veterinary Clinical Pathology, Baton Rouge, v. 35, n. 4, p. 413-417, 2006.

DE TOMMASI, A. S.; OTRANTO, D.; FURLANELLO, T.; TASCA, S.; CANTACESSI, C.; BREITSCHWERDT, E. B.; STANNECK, D.; DANTAS-TORRES, F.; BANETH, G.; CAPELLI, G.; CAPRARIIS, D. Evaluation of blood and bone marrow in selected canine vector-borne diseases. Parasites \& Vectors, London, v. 2 , n. 7, p. 1-10, 2014.

IKEDA-GARCIA, F. A.; CIARLINI, P. C.; LOPES, R. S.; MARQUES, F. J.; BOMFIM, S. R. M.; LIMA, V. M. F.; PERRI, S. H. V.; MARCONDES, M. Hematological evaluation of dogs naturally infected by Leishmania (Leishmania) chagasi submitted to treatment with meglumine antimoniate. Brazilian Journal of Veterinary Research and Animal Science, São Paulo, v. 45, p. 68-74, 2008. Supplement.

JAIN, N. C. Essentials of veterinary hematology. Malvern: Lea \& Ferbinger, 1993. 407 p.

KEARNS, S. A.; EWINGS, P. Causes of canine and feline pancytopenia. Compendium on Continuing Education for the Practising Veterinarian, Yardley, v. 28, n. 2, p. 122-134, 2006.

LACHAUD, L.; MARCHERGUI-HAMMAMI, S.; CHABBERT, E.; DEREURE, J.; DEDET, J. P.;BASTIEN, P. Comparison of six PCR methods using peripheral blood for detection of canine visceral leishmaniasis. Journal of Clinical Microbiology, Washington, v. 40, n. 1, p. 210-215, 2002.

MUHURY, M.; MATHAI, A.; NAIK, R.; PAI, M.; RAI, S.; SINHA, R. Megakaryocytic alterations in thrombocytopenia: a bone marrow aspiration study. Indian Journal of Pathology and Microbiology, Mumbai, v. 52, n. 4, p. 490-494, 2009.

MURPHY, G. L.; EWING, S. A.; WHITWORTH, L. C.; FOX, J. C.; KOCAN, A. A. Molecular and serologic survey of Ehrlichia canis, Ehrlichia chaffeensis, and E. ewingii in dogs and ticks from Oklahoma. Veterinary Parasitology, Amsterdan, v. 79, n. 4, p. 325-339, 1998.

REBAR, A. H. General responses of the bone marrow to injury. Toxicologic Pathology, Thousand Oaks, v. 21, n. 2, p. 118-129, 1993. 
SAMBROOK, J.; FRITSCH, E. F.; MANIATIS, T. Molecular cloning: a laboratory manual. $2^{\text {th }}$ ed. New York: Cold spring Harbor Laboratory Press, Cold Spring Harbor, 1989. v. 1, 1626 p.

SILVA, J. N.; ALMEIDA, A. B. P. F.; BOA SORTE, E. C.; FREITAS, A. G.; SANTOS, L. G. F.; AGUIAR, D. M.; SOUSA, V. R. F. Soroprevalência de anticorpos antiEhrlichia canis em cães de Cuiabá, Mato Grosso. Revista Brasileira de Parasitologia Veterinária, Jaboticabal, v. 19, n. 2, p. 108-111, 2010.

STACY, N. I.; HARVEY, J. W. Bone marrow aspirate evaluation. The Veterinary Clinics: Small Animal Practice, Philadelphia, v. 47, n. 1, p. 31-52, 2017.

STOKOL, T. Bone marrows: unraveling the mystery. International SCIVAC Congress, Rimini, v. 1, n. 1, p. 229-230, may 2010.

WEINZIERL, E. P.; ARBER, D. A. Bone marrow evaluation in new-onset pancytopenia. Human Pathology, Philadelphia, v. 44, n. 6, p. 1154-1164, 2013.
WEISS, D. J. A retrospective study 1999 of the incidence and the classification of bone marrow disorders in the dog at a veterinary teaching hospital. Journal of Veterinary Internal Medicine, Philadelphia, v. 20, n. 4, p. 955-961, 2006.

. New insights into the physiology and treatment of acquired myelodysplastic syndromes and aplastic pancitopenia. The Veterinary Clinics: Small Animal Practice, Philadelphia, v. 33, n. 6, p. 1317-1334, 2003.

.Recognition and classification ofdysmyelopoiesis in the dog: a review. Journal of Veterinary Internal Medicine, Philadelphia, v. 19, n. 2, p. 147-154, 2005.

WEISS, D. J.; EVANSON, O. A.; SYKES, J. A. retrospective study of canine pancytopenia. Veterinary Clinical Pathology, Baton Rouge, v. 28, n. 3, p. 83-88, 1999. 